\title{
STRIDEN OM DØDEHAVSRULLERNE
}

En videnskabsteoretisk case

\author{
Anita Holm Riis
}

Videnskabsteoriens ofte generelle og overordnede refleksioner over, hvad viden og videnskab er eller bør være, har mindst ét problem: Den mangler gode, aktuelle eksempler fra det praktiske niveau, hvor forskningen foregår. Ikke mindst når det gælder kulturforskningen, er dette tilfældet. De mange videnskabshistoriske analyser, der findes (herunder f.eks. Thomas Kuhns), dementerer ikke denne påstand. Her er eksemplerne sjældent aktuelle og sjældent fra kulturforskningens områder. Når denne gren af videnskaberne er underrepræsenteret i videnskabsteoriens eksempelmateriale, kan det skyldes, at kulturforskningens begreber er diffuse. F.eks. kan man ikke på samme kontante måde som i naturvidenskaberne illustrere betydningen af betegnelser som 'sandt' og 'falsk'. Sådan ser det i hvert tilfælde ud for en umiddelbar betragtning. Jeg vil tillade mig at vende det synspunkt lidt på hovedet: Kulturforskningen kan være særdeles kontant og skarp - herunder i sin skelnen mellem sandt og falsk. Det vil jeg argumentere for v.h.a. et aktuelt eksempel fra kulturforskningens område. Her afspejles i opfattelsen af, hvad god videnskabelig praksis er, et markant objektivitetsbegreb.

Min case er blevet kaldt 'striden om dødehavsrullerne' og refererer til en række diskussioner, som fulgte i kølvandet på fundene af dødehavsrullerne i årene 1947-56. Netop fordi denne sag har udviklet sig til en strid, har den også udviklet sig til en diskussion om det, man kan kalde god videnskabelig praksis. Uenighederne har i dette tilfælde synliggjort nogle af de mest fundamentale præmisser for forskningen. Dermed bliver grundlaget for en videnskabsteoretisk analyse tilgængeligt, fordi den netop undersøger sådanne præmisser. Jeg vil i det følgende diskutere kulturvidenskabernes objektivitetsbegreb i forlængelse af to videnskabsteoretiske problemer, som bliver centrale i striden om dødehavsrullerne. Det første problem vedrører forholdet mellem forskeren og forskningen. Er forskerens mål nødvendigvis i overensstemmelse med forskningens? Det andet problem relaterer sig til hypotesers status. Hvordan vurderer man inden for dødehavsrulleforskningen, om en hypotese er gyldig?

Inden jeg bevæger mig til diskussionen af disse spørgsmål, vil jeg understrege, at mine referencer til empirien (striden om dødehavsrullerne) ikke vil være detaljerede, eftersom jeg kun uddrager det, som er direkte relevant for den videnskabsteoretiske behandling. Jeg vil også nævne, at en del af mit analysegrundlag består af en række direkte meningstilkendegivelser fra forskere, hentet fra en tv-udsendelse om dødehavsrullerne. Det, som i litteraturen fremsættes mere forsigtigt, fremstår her utvetydigt. Den direkte form får forskernes grundholdninger frem i lyset. Derfor er det et godt materiale til belysning af stridens videnskabsteoretiske præmisser.

Artiklen skal vise, at de holdninger og argumenter, forskerne fremsætter, forudsætter 
et objektivitetsbegreb, som sjældent kommer til syne i kulturforskningen. Som sådan er artiklen det, man kunne kalde en 'forudsætningsanalyse’.

\section{Om forholdet mellem forskeren og forskningen}

Ca. 800 dokumenter og fragmenter blev hovedsageligt i tidsrummet 1947-56 fundet i hulerne omkring det sted, der er kendt som Qumran. Det viste sig allerede i forbindelse med de første fund, at der var tale om et materiale, som kunne tænkes at få betydning for forståelsen og fortolkningen af centrale tekster i såvel Det gamle som Det nye Testamente - m.a.o. få betydning for såvel jødedommen som kristendommen. Potentialet for en strid var nærmest til stede fra begyndelsen. Det der skete efterfølgende, gjorde ikke dette potentiale mindre. I de første år blev adskillige dokumenter offentliggjort, men efter 1956 begyndte det at gå langsommere - meget langsommere. Fundene af især en enorm mængde fragmenter besværliggjorde publikationsarbejdet. Fragmenterne skulle, i det omfang det var muligt, stykkes sammen, og på Palæstinas Arkæologiske Museum i Østjerusalem, hvor skrifterne nu var samlet, indså man hurtigt, at der her var tale om en opgave, som krævede ekstraordinær hjælp. Otte forskere med dominikaner-præsten Roland de Vaux i spidsen gik på anvisning af den jordanske regering i gang med arbejdet (VanderKam 1994, 189). Hvad der i den forbindelse vakte undren, var det faktum, at arbejdsgruppen bestod af forskere med udelukkende kristen baggrund. Dødehavsrullerne indeholdt mængder af jødisk tankegods - som dermed ikke umiddelbart ville være tilgængeligt for andre end en gruppe kristne forskere, mente man. Problemet var næppe blevet så stort, hvis udgivelserne var udkommet inden for en rimelig tidsramme, men de blev sjældnere og sjældnere. Fra 1967-77 gik publikationsarbejdet så godt som i stå. Først i 1990 blev det samlede materiale tilgængeligt for de mange forskere verden over, som måtte have interesse for emnet. ${ }^{1}$ De havde ventet $\mathrm{i}$ årtier på at få adgang til tekster med stor forskningsmæssig betydning.

\footnotetext{
${ }^{1}$ For nærmere detaljer kan jeg henvise til kap.7 i VanderKam 1994, hvor også de politiske forhold mellem Jordan og Israel bliver en vigtig del af historien.
} 
Her er det netop, at et væsentligt videnskabsteoretisk problem bliver aktuelt: I hvilken udstrækning er forholdet mellem forskerens og forskningens mål sammenfaldende? Man kan vælge at betragte den enkelte forskers arbejde som et bidrag til forskningens overordnede mål. I så fald er forskningen bedst tjent med, at så mange forskere som muligt får chancen for at give deres meninger, fortolkninger og hypoteser til kende. Nu er dødehavsrullerne et skrøbeligt materiale, som må behandles med omhu. Dette var et af argumenterne for, at skrifterne kun var tilgængelige for en mindre gruppe. ${ }^{2}$ Men spørgsmålet er, om der blandt arbejdsgruppens medlemmer også var andre motiver til stede, som i højere grad tjente private forskningsmæssige mål end et hensyn til forskningen som sådan. Havde der blandt gruppens medlemmer været et brændende ønske om hurtigst muligt at få gjort dette enestående materiale tilgængeligt, således at flest mulige forskere kunne bidrage med fortolkninger, ville publikationsarbejdet næppe have været så langsommeligt. M.a.o. var der god grund til at mistænke arbejdsgruppen for at have personlige motiver indblandet i denne affære. Undervejs i forløbet kom der ganske vist nye forskere til, når ældre medlemmer faldt fra, men disse var gennemgående tro elever af gruppens medlemmer. Hvad kunne disse personlige motiver da være? Een ting vil næppe nogen forsker kunne sige sig fri for: Hvis man er så heldig at få adgang til et både unikt og væsentligt materiale, som ingen tidligere har haft mulighed for at analysere, vil man sikkert ikke være tilbøjelig til, som det første, at dele sit held med resten af verden. Mon ikke de fleste i den situation ville være fristede til at opretholde en vis grad af hemmelighedskræmmeri? Noget ganske andet er, om dette er rimeligt. Kulturvidenskaberne lever af at fortolke, analysere og udarbejde hypoteser (ikke nødvendigvis i nævnte rækkefølge), og det var netop det, mange blev forhindret og forsinket i. Der blev hurtigt grundlag for rygtedannelser, fordi 'den heldige gruppe’ af kristne forskere holdt særdeles hårdt på deres ret til at være de eneste med adgang til dødehavsrullerne.

I en tv-udsendelse fra 1993 interviewer BBC en række forskere, som alle på den ene eller anden måde har beskæftiget sig med områder, hvor dødehavsteksterne hypotetisk set kunne indeholde væsentlige oplysninger. Fælles for dem er en irritation over, at de har måttet vente i årevis på at få adgang til et betydningsfuldt materiale. Professor Lawrence Schiffman (Department of Near Eastern Studies, New York University) siger f.eks. følgende:

Why weren't they published, why were they held private? A lot of reasons: alcoholism, death and disease of some of the scholars, selfishness, greed, the ability to use them to

\footnotetext{
${ }^{2}$ Et andet argument var, at arbejdet var ulønnet. Skulle det kunne tiltrække forskere, som alligevel ville bruge deres tid på det, måtte de have noget til gengæld, nemlig retten til at sidde i ro og mag med materialet til de var færdige med det.
} 
place your students - all types of motives which never should have existed (BBC 1993, s.10).

Nogle gik så vidt som til at hævde en konspirationsteori: Når publikationsarbejdet gik så langsomt, måtte det være fordi, skrifterne indeholdt kontroversielle oplysninger - f.eks. om kristendommens oprindelse. Vatikanet kunne dermed have en interesse i at tilbageholde materialet. Som vi skal se, bliver disse gisninger om sammenhængen mellem dødehavsrullerne og kristendommen centrale for to af de hypotesedannelser, der senere skaber endnu mere furore i sagen. I den nævnte tv-udsendelse fra 1993 afvises konspirationsteorien dog af bl.a. Father Jerome Murphy-O’Connor fra Ecole Biblique i Jerusalem. Han siger følgende:

Recent discussion of the scrolls has been dominated by a conspiracy theory: that a prescient Vatican, long before any of the scrolls were read, realised they would be tremendously dangerous, and so slipped in people in inquisitor's robes to ensure that the scrolls were never published. That's an absolutely ridiculous theory. The Vatican isn't interested in controlling historical research ... (BBC 1993, 9).

De to citater taler deres tydelige sprog: Rygter, beskyldninger og mere eller mindre seriøse gisninger har blandet sig med kravet om, at enhver forsker principielt bør have adgang til data, som (hvis de eksisterer) er vigtige for hans/hendes forskning. ${ }^{3}$

Ideelt set burde forskningens og forskerens mål være sammenfaldende. Forestillingen om, at det, den enkelte bidrager med, skal indgå i en større sammenhæng - hvorved den enkelte må tilsidesætte personlige interesser - afspejler et videnskabsideal, som de fleste vil kunne tilslutte sig. En klassisk videnskabsteoretisk diskussion belyser dette

\footnotetext{
${ }^{3}$ Det har i den forbindelse været hævdet (herunder i tidsskriftet Nature), at det i naturvidenskaberne havde været utænkeligt at tilbageholde vigtige data over en så lang periode. Det betyder dog ikke, at man aldrig tilbageholder oplysninger, når det gælder naturvidenskab. Tværtimod er det her ganske almindeligt, at man hemmeligholder data i en vis årrække. F.eks. vil de informationer, der kommer ned fra Ørsted-satellitten næppe blive tilgængelige for alle med det samme. De er forbeholdt deltagerne i projektet. Derfor er diskussionen mest et spørgsmål om, hvor lange man kan tilbageholde data - ikke om hvorvidt man kan gøre det.
} 
tema. Både Karl Popper og Thomas Kuhn giver et bud på, hvad der får forskeren til at forske. $^{4}$

For Popper er sandhedsbegrebet kernen i mange af hans videnskabsteoretiske overvejelser (Popper 1996). Det er hans overbevisning, at videnskab kun bliver et meningsfyldt fænomen, hvis det forstås som en proces, der udvikler sig i kraft af en tilpasning til sandheden. Når ny viden skabes, afløser den ofte antagelser af ældre dato, som nu viser sig at være fejlagtige. Uden dette bestandige spil mellem sandt og falsk, hvor altså sandere viden afløser falsk (eller falsificeret) viden, bliver det problematisk at begrunde videnskabelig udvikling. Uden et begreb om videnskabelig udvikling bliver det svært at se meningen med det, en forsker foretager sig. Uden en målestok (som udvikling eller sandhed) for det, der foregår i forskningsprocessen, bliver det således svært at besvare, hvorfor man forsker. Den enkelte forskers aktiviteter kan derfor ikke ses uafhængigt af det, der på et overordnet niveau gør sig gældende i videnskaben, nemlig bevægelsen frem mod en bedre, mere præcis og i Poppers terminologi mere sand afdækning af verdens beskaffenhed (Popper 1972). Denne formulering lyder muligvis fremmed for en kulturforsker, men efter min opfattelse er det dybest set den samme tankegang, der gør sig gældende, når argumenterne hentes frem mod den langsomme publikation af dødehavsskrifterne. Også i kulturvidenskaberne er det en uskreven regel, at hypoteser bør konfronteres med kilder (her tekster) som evt. ville kunne afvise dem. Forskningens 'drift' ligger også her i spillet mellem sandt og falsk. Dr. Philip Davies (Department of Biblical Studies, University of Sheffield) fortæller følgende:

Even when I went to Israel to try to get hold of somebody who could give me permission, I got bounced around from one place to another. It was also frustrating because I was researching on some of the scrolls and I knew that there were fragments of this document unpublished, sitting on somebody's desk, and I knew that whatever I said could be entirely contradicted by something that somebody else had, wasn't working on, wouldn't let me see. That's an impossible situation to be in. I would have understood if the person had said: 'look at the texts, you can't publish them, but if you want to satisfy yourself that there's nothing in there you really need, fine'. I didn’t even get that (BBC 1993, 9).

Kildematerialet i dødehavsteksterne giver, hvis jeg forstår Davies korrekt, mulighed for at udelukke eventuelle fejlagtige opfattelser af allerede kendte tekster. Hans udtalelse

\footnotetext{
${ }^{4}$ Jeg overfører i det følgende et tema hos Popper og Kuhn til kulturforskningens område vel vidende, at de ofte kun anses for relevante i naturvidenskaberne (og for Poppers vedkommende måske også i sociologien). Jeg mener dog, at de begge behandler en række principielle spørgsmål angående forskningens grundlag, som også kan diskuteres i en kulturvidenskabelig kontekst.
} 
forudsætter visse standarder for god forskning. F.eks. bliver gyldighed forbundet med grundighed: Man kan ikke udarbejde en pålidelig fortolkning uden at tage højde for alle tilgængelige data/kilder. Grundigheden er altså forbundet med falsifikationen, dvs. med muligheden for at lade sine hypoteser kollidere med noget, her tekster. Davies' objektivitetsbegreb indeholder en forestilling om, at man i forskningen må tage højde for alle tilgængelige data, som måtte kunne modsige ens fortolkninger og hypoteser. Den bevægelse mellem sandt og falsk, som hos Popper gøres til noget fundamentalt i den videnskabelige proces, synes også at være vigtig her.

Poppers ‘sandhedssøgende forsker' er ikke et blot ideal, men derimod afgørende for at kunne give mening til og dermed opretholde videnskaberne. Netop derfor er det interessant, at Kuhn peger på nogle helt andre faktorer, når han skal besvare spørgsmålet om, hvad der får forskeren til at forske. Det, der iflg. Kuhn afgør, om en forsker er en god forsker, er evnen til at løse gåder (puzzle-solving) (Kuhn 1970). Det skyldes ikke mindst, at det centrale for ethvert videnskabeligt fagområde er opretholdelsen og bekræftelsen af dets paradigme. ${ }^{5}$ At kunne løse de videnskabelige problemer man beskæftiger sig med, bidrager til at styrke paradigmet. Derfor bliver selve problemløsningen en klar kvalitet, som forskeren kan vurderes på. At løse et problem, bliver dermed den essentielle drivkraft for forskeren. Det er herved man beviser sin duelighed som forsker. ${ }^{6}$ Forskeren og paradigmet kan ikke ses uafhængigt af hinanden. Til gengæld er paradigmet og dermed også forskeren uafhængige af en overordnet forskningsstrategi, som måtte gå på tværs af fagområder. Når et paradigme søges opretholdt, sker det helt på dets egne præmisser. Relationen til andre fagområder er i den forbindelse sekundær. Fra et kuhnsk perspektiv er der ikke og kan der ikke findes noget som 'videnskabens overordnede mål'. En sådan målestok forudsætter fælles standarder for god forskning på tværs af paradigmer. Det dilemma, som set fra en poppersk vinkel kan opstå mellem den enkeltes motiver og videnskabens overordnede mål, er ikke aktuelt her.

I sagen om dødehavsrullerne rækker argumenterne og kritikken ud over det, man ville kunne kalde et paradigme. Argumenterne går ikke på fagområdets udvikling, men i højere grad på idealer for forskningen generelt. Den argumentation, vi finder i forbindelse med kravet om adgang til dødehavsteksterne, fremhæver de popperske idealer om en overordnet forskningsetik styret af kravet om objektivitet, herunder muligheden for at kunne falsificere. I de seneste år er det blevet diskuteret, hvorvidt kulturforskningen er blevet for subjektivistisk. ${ }^{7}$ I striden om dødehavsrullerne, hvor

\footnotetext{
${ }^{5}$ Paradigmet er Kuhns samlede betegnelse for de teorier, metoder og spilleregler (skrevne som uskrevne), som danner grundlag for et videnskabeligt fagområdes arbejdsfelt. Paradigmet afstikker så at sige både de tekniske og normative rammer for, hvordan forskeren kan og bør arbejde og med hvad.

${ }^{6}$ Påstanden styrkes af det forhold, at vi i realiteten aldrig formulerer et problem uden forventningen om at kunne løse det.

${ }^{7}$ Det er ikke mindst sket i forlængelse af fysikeren Alan Sokals artikel i tidsskriftet Social Text (1996). Ifølge Sokal selv var artiklen rent nonsens, som byggede på en konstrueret sammenhæng mellem bl.a. en række kendte franske filosoffer og kvantefeltteori. Spørgsmålet er, hvordan et anerkendt tidsskrift kunne
} 
synspunkterne trækkes skarpt op i kraft af uenighederne, er det de klassiske dyder om, hvad god forskning er, der anvendes i argumentationen. Her virker det ikke, som om objektivitetsbegrebet står svagt.

Alt dette betyder naturligvis ikke, at forskere ikke har forskellige mål, hvoraf nogle kan være personlige, men spørgsmålet er, hvor langt man kan efterstræbe sine private mål uden at komme i konflikt med det, der giver forskningen mening. Set fra et poppersk perspektiv må der før eller siden opstå et sådant dilemma, hvis man i sin forskning forfølger de rent personlige motiver.

Striden om dødehavsrullerne er ikke blot en strid om adgang til et væsentligt kildemateriale. Efterhånden som forskerne verden over endelig får mulighed for at fortolke og analysere tekstmaterialet, præsenteres vi følgelig også for hypoteser om dets indhold. Nogle af disse hypoteser vækker forargelse og afvises som direkte usande. Objektivitetsidealerne synliggøres igen.

\section{Om hypotesers status}

Som nævnt byggede konspirationsteorien på den hypotese, at dødehavsrullerne måtte indeholde informationer, som kunne være problematiske for kristendommens selvopfattelse. Teksterne hører tidsmæssigt hjemme omkring vor tidsregnings begyndelse. En helt præcis datering af teksterne er næppe mulig, men v.h.a. f.eks. palæografi, som daterer ud fra selve skrivestilen, kan man komme tæt på. Palæograferne hævder at kunne datere inden for en margen på 25-50 år (VanderKam 1994, 16). En særligt udviklet kulstof 14-metode (accelerator mass spectrometry) er også blevet anvendt på et udvalg af dødehavsrullerne, men her er margen for datering større. En tredie mulighed for datering er identificeringen af personer eller begivenheder, som man allerede har tidsfæstet. Sammenholdes metoderne, er der en vis overlapning mellem især den palæografiske metode og accelerator mass spectrometry-metoden. Her viser det sig, at den overvejende del af dødehavsdokumenterne må placeres i det første og andet århundrede f.Kr. og få i det første århundrede e.Kr. (VanderKam 1994, 18).

Spørgsmålet er, hvilken status man tillægger de forskellige dateringsmetoder, når teksterne skal fortolkes. Robert Eisenman og Barbara Thiering er to af de forskere, som mener at kunne se stærke paralleller mellem Det Nye Testamente og en af de historier, der fortælles i dødehavsdokumenterne (VanderKam 1994, 161). De mener derfor begge,

antage en sådan artikel. Sokal hævdede, at den subjektivistiske tendens inden for kulturstudierne havde taget over: Hvis man m.a.o. blot kan konstruere en sammenhæng mellem tilsyneladende uafhængige fænomener og teorier, er der intet, der forhindrer os i at retfærdiggøre dette som et gyldigt bidrag til kulturforskningen. 
at flere af teksterne end antaget må høre hjemme i tiden efter Kristi fødsel. Dette er en vigtig forudsætning for deres respektive hypoteser, som jeg skal vende tilbage til.

Når man hører om en af de beretninger, der fortælles i skrifterne, bliver det klart, hvorfor Eisenman og Thiering placerer teksterne, som de gør. Der bliver også kastet lys over, hvordan konspirationsteorien kunne opstå. Hovedpersonen i denne beretning er en lederskikkelse, som kaldes 'Retfærdighedens lærer'. Han er omgivet af en gruppe tro følgesvende. Han bliver udsat for forfølgelse, forvisning og muligvis henrettelse. Bag dette står en anden af beretningens centrale personer, 'Den onde præst', som igen er i opposition til en mand kaldet 'Løgneren'. Det hele foregår under fremmede magthavere. Forfatterne til denne beretning er de omtalte følgesvende, som både før og nu har viet deres liv til den nu afdøde lærer (BBC 1993, 6).

Striden om dødehavsrullerne udvikler sig nu til en diskussion om, hvem disse personer kan være. Der er slående paralleller mellem det, der her fortælles, og Det Nye Testamentes fortællinger. Diskussionen drejer sig derfor om, hvad man kan konkludere på baggrund af sådanne paralleller. Kan man f.eks. datere ud fra dem, hvis man i øvrigt kan få personerne i dødehavsrullerne identificeret med personer fra nytestamentlig tid? Det er under alle omstændigheder, hvad Eisenman og Thiering gør, vel at mærke med to helt forskellige resultater.

Eisenman identificerer Retfærdighedens lærer som Jesu bror, Jakob, og Løgneren som Paulus. Thiering mener derimod, at Den onde præst og Løgneren er en og samme person, nemlig Jesus selv. Selvom der her er tale om to meget forskellige synspunkter, kan Eisenman og Thiering være enige om, at mange af teksterne nødvendigvis må dateres senere, end de fleste forskere antager. Netop dette synspunkt, hvor parallellerne mellem Ny Testamente og dødehavsdokumenterne gøres til det egentlige dateringsgrundlag, har virket provokerende. Eisenman og Thiering nægter dermed at acceptere ellers anerkendte dateringsprincipper. Eisenman understreger, at den metode, hvor en tekst dateres ud fra historisk kontekst, er og bliver den sikreste. Han går så vidt som til at hævde, at "even if the carbon testing or the palaeography came out to counterindicate it, I would not accept it” (BBC 1993, 18).

En af Eisenmans ihærdige modstandere er professor Lawrence Schiffman fra New York University. Han lægger ikke skjul på, at Eisenmans hypotese er direkte forkert. Schiffman og Eisenman havde denne 'meningsudveksling', da de mødtes på en konference i begyndelsen af 1990'erne:

Professor Robert Eisenman: "Go on, hit me, hit me, come on Larry. I like to hit you too. Right let's keep at it. We can go all night with you. Long as I'm up here and you're down there."

Professor Lawrence Schiffman: "This theory is nonsense. It's nonsense because of the fact that it places the corpus ..."

Professor Robert Eisenman: "That's not the way I talk about your work. I think you should be a little more respectful."

Professor Lawrence Schiffman: "You may be right, in which case I apologise ... This theory is unacceptable." 
Professor Robert Eisenman: "One thing Larry does is he speaks so loud and aggressively...” (BBC 1993, 3-4).

Og sådan fortsætter denne ‘akademiske’ meningsudveksling. Kernen i Schiffmans kritik (som ikke helt kommer til sin ret her) er, at Eisenman ignorerer et af de basale principper for vurderingen af et historisk tekstkorpus, nemlig en seriøs dateringsteknik. Eisenman anvender den usikreste af alle metoder, mens de fleste andre forskere anvender flere metoder i håb om at få en så præcis datering som mulig. Vi er dermed tilbage ved det samme argument, som gjorde sig gældende i forbindelse med publikationsstriden. Grundighed underbygger gyldigheden af en hypotese, fordi der herved tages højde for flere faktorer, som kan kollidere med hypotesen. Når Eisenman vælger kun at tage en enkelt dateringsmetode alvorligt, får han lettere ved at bekræfte sin hypotese, fordi der dermed bliver mindre risiko for modsigelser. Set ud fra et ønske om størst mulig objektivitet i forskningen bliver det problematisk at acceptere Eisenmans fremgangsmåde. Uden et stærkt objektivitetsbegreb ville Eisenmans hypotese altså ikke udgøre noget problem.

Schiffman er som antydet ikke ene om sit synspunkt. Dog har andre forskere været knapt så provokerede. James VanderKam bagatelliserer ligefrem et synspunkt som bl.a. Eisenmans:

Still today some scholars draw Christianity and the scrolls into much closer proximity than the mainline view allows, but they have convinced few if any and are generally taken more seriously by the media than by their colleagues. They tend to reject the paleographical and archeological evidence that has been used to date the scrolls to earlier times than their hypotheses demand (VanderKam 1994, 161).

Som VanderKam siger, har medierne interesseret sig mere for disse hypoteser, end forskerne har. ${ }^{8}$ Spørgsmålet er, om de 'vilde’ hypoteser alligevel har en funktion set fra et overordnet forskningsmæssigt perspektiv? Barbara Thierings forskning kan måske besvare dette spørgsmål for os.

Ifølge Thiering er Den onde præst og Løgneren som nævnt een og samme person nemlig Jesus. Disse to negativt ladede betegnelser kom fra hans modstandere, som krævede jødisk overherredømme. Dette og meget andet kan man, ved hjælp af en særlig fortolkningsmetode (pesher-metoden) læse i dødehavsrullernes beretninger. Ifølge Thiering indeholder de religiøse tekster et budskab under overfladen, som leder os direkte til de historiske facts, den sande historie (Thiering 1993, 24). Under overfladen på en religiøs tekst fortælles m.a.o. om faktiske historiske begivenheder. Når Jesus f.eks. forvandler vand til vin, handler det i realiteten om noget helt andet. Qumran havde

\footnotetext{
${ }^{8}$ Mediernes store interesse hænger bl.a. sammen med konsekvenserne af Thierings og Eisenmans hypoteser. Eisenmans synspunkter vil f.eks., hvis de holder, ændre radikalt ved vort billede af kristendommen som en pacifistisk religion. Eisenman selv mener, at dette er en af de væsentligste grunde til modstanden mod hans teori. Der skulle m.a.o. være en skjult dagsorden hos hans modstandere, som 'pakkes ind' i et dateringsspørgsmål.
} 
et indvielsesritual, som understregede et hierarki ved at give vand til nogle og vin til andre. Når Jesus således omdanner vand til vin, er det blot en fortælling om, at alle i hans øjne burde være lige - alle skulle f.eks. have ret til at blive præster. På samme måde beretter dødehavsteksterne om noget helt konkret og rationelt. Ved at anvende pesher-metoden på dødehavsrullernes fortælling om Retfærdighedens lærer, Den onde præst og Løgneren mener Thiering således at kunne identificere disse personer. Dermed får hun samtidig dateret teksterne. Her kunne jeg gentage kritikken af Eisenman. Når Eisenman stadig tages mere alvorligt end Thiering, skyldes det, at Thierings teori går endnu videre. Ved hjælp af pesher-metoden genfortæller hun Jesu liv således, at miraklerne, herunder opstandelsen, bliver forklaret på et rationelt grundlag. Jesus blev f.eks. kun forsøgt henrettet, men henrettelsen slog i virkeligheden fejl. Opstandelsen var derfor ikke en opstandelse fra de døde, men den endnu levende Jesus. Thiering mener selv, at hendes teori kan efterprøves ud fra kravet om konsistens. Hvis man konsekvent anvender hendes læsemetode, vil historien således udgøre en helhed uden indre modsigelser. Derfor er den sand, mener Thiering.

Hvorfor skal vi overhovedet forholde os til en vild hypotese som Thierings? Jeg mener faktisk, at den har mindst en vigtig funktion: Forskningen bevæger sig ikke uden provokationer.

Både Thiering og Eisenman har tvunget andre forskere inden for samme felt til at præcisere deres synspunkter. Det at få formuleret, hvorfor Thierings og Eisenmans hypoteser ikke kan være sande, er en udfordring til kulturvidenskabernes objektivitetsbegreb. I den rutinerede videnskabelige arbejdsproces forbliver kriterierne for, hvad man anser for værende god forskning implicitte. I striden om dødehavsrullerne bliver denne implicitte viden mere eksplicit. Og det er her, jeg mener at kunne identificere et objektivitetsbegreb, som sjældent kommer til syne i kulturforskningen.

Uanset om den moderne videnskab har givet køb på ideen om absolut sandhed og objektivitet, lever begreberne videre. Vi må bestandigt se vore hypoteser forandret og måske afvist, og vi forklarer denne proces via begreberne sandt og falsk. Divergerende filosofiske sandhedsteorier ændrer ikke på, at forestillingen om objektivitet stadig i praksis spiller en afgørende rolle for forskningen Striden om dødehavsrullerne er et klart eksempel.

\section{Konklusion}

Jeg har ovenfor forsøgt at synliggøre kulturforskningens objektivitetsbegreb via dødehavsrulleforskningen. Det er sket dels ud fra en analyse af forholdet mellem forskeren og forskningen, dels ud fra en diskussion angående hypotesers status.

M.h.t. forholdet mellem forskeren og forskningen har jeg med udgangspunkt i Poppers og Kuhns klare holdninger til, hvad der får forskeren til at forske, peget på, at den langsommelige publicering af dødehavsrullerne har fået kritikere til at fremhæve en overordnet forskningsetik, som er knyttet til kravet om objektivitet. Hvorvidt objektivitet er mulig i egentlig forstand, er på sin vis underordnet. Her viser den sig som 
en klar målestok hos forskerne. Argumenterne peger således ud over det enkelte fagområdes paradigme i retning af kriterier, som går på tværs af videnskaberne.

Spørgsmålet om, hvorvidt vi inden for kulturforskningen kan afklare en hypoteses status, implicerer ligeledes objektivitetsbegrebet. Eisenmans og Thierings hypoteser afvises af flere som direkte forkerte. Det er kun muligt, hvis man forudsætter, at fortolkninger kan være i modstrid med noget, der anses for værende mere sandt. Det spil mellem sandt og falsk, som nødvendigvis må relatere sig til et objektivitetsbegreb, er således ikke kun et fænomen, man møder i naturvidenskaben.

Falsifikationen står tilsyneladende stærkt hos dødehavsrulleforskerne. Er der m.a.o. tilgængelige data eller kilder, som strider imod en hypotese, skal de tages alvorligt. I det afgørende dateringsspørgsmål vælger Eisenman og Thiering ifølge deres kritikere at ignorere de metoder, som sikrer en hypoteses holdbarhed. I stedet for at anvende en falsifikationistisk procedure lader de to forskere deres hypoteser verificere: De inddrager kun de data og metoder, som bekræfter deres antagelser, mens alt andet udelades. På sådanne præmisser kan de fleste skabe en konsistent hypotese. Striden om dødehavsrullerne er et eksempel på, at der inden for kulturforskningen stadig findes et fremherskende krav om objektivitet, som umuligt kan lade konsistens være det eneste kriterium for en hypoteses holdbarhed.

\section{Litteratur}

BBC 'Resurrecting the Dead Sea Scrolls', Text adapted from the programme transmitted 22nd March 1993, London.

EISENMAN, ROBERT \& MiCHAEL WISE

1992 The Dead Sea Scrolls Uncovered, Shaftesbury.

KuHN, ThOMAs S.

1970 The Structure of Scientific Revolutions, Chicago.

POPPER, KARL R.

1996 Kritisk rationalisme, København.

1972 Objective Knowledge, Oxford.

THIERING, BARBARA

1993 Mennesket Jesus. En ny fortolkning af Dødehvsrullerne, Viborg.

VANDERKAM, JAMES C.

1994 The Dead Sea Scrolls Today, Grand Rapids.

\section{Summary}

Traditionally, the concept of objectivity has been connected with the natural sciences rather than the cultural sciences. In recent years there has even been talk of an outright subjectivist tendency in cultural research. The present article takes issue with this prejudice. Here a concrete example from the field of cultural studies is analysed (the dispute concerning the Dead Sea Scrolls) with the intention of laying bare the underlying concept of objectivity. The example shows that research in this field presupposes a distinct concept of objectivity.

\section{Anita Holm Riis}


Anita Holm Riis

Ekstern lektor, cand.mag.

Institut for Religionsvidenskab

Aarhus Universitet 